\title{
PENINGKATAN HASIL BELAJAR SISWA PADA KD 3.6 MENJELASKAN DAN MENEMUKAN JARING-JARING BANGUN RUANG SEDERHANA (KUBUS DAN BALOK) MELALUI PENGGUNAAN MEDIA BENDA KONKRET DI KELAS V SD NEGERI 5 MADUREJO TAHUN PELAJARAN 2017/2018"
}

\author{
SUSILAWATI, S.Pd SD \\ NIP. $1967 \mid 227$ | $987 \mid 22002$ \\ SD NEGERI 5 MADUREJO
}

\begin{abstract}
Abstrak
Sekolah Dasar (SD) merupakan jenjang paling dasar dalam pendidikan formal di Indonesia. Sekolah dasar dilaksanakan dalam waktu 6 tahun, mulai dari kelas $V$ sampai kelas 6 . Lulusan sekolah dasar dapat melanjutkan pendidikan ke sekolah menengah pertama (SMP) atau yang sederajat. Sekolah Dasar diselenggarakan oleh pemerintah maupun swasta. Di Indonesia pada saat ini, anak usia SD dimulai dari 6 tahun sampai dengan 12 tahun. Secara psikologis, periode ini dikategorikan Masa Kanak-kanak Akhir. Para pendidik masa tersebut sebagai "Masa Sekolah Dasar" sedangkan para psikolog menyebutnya sebagai "Masa Berkelompok" atau "Masa Penyesuaian Diri".

Penggunaan media benda konkret dapat diterapkan pada kelas yang mempunyai karakteristik seperti kelas yang dijadikan subjek penelitian ini. Hendaknya pembelajaran dengan Penggunaan media benda konkret ini dicoba untuk diterapkan pada mata pelajaran yang lain.

Kata Kunci: Hasil Belajar, Jaring-jaring bangun ruang, media benda konkret
\end{abstract}

\section{PENDAHULUAN}

Pembelajaran yang dilakukan di sekolah meliputi berbagai hal yang semua terangkum dalam mata pelajaran yang diberikan serta ketrampilan atau pengetahuan lain. Beberapa mata pelajaran dikenal sebagai mata pelajaran yang menjadi stressor utama dalam proses belajar di sekolah antara lain adalah mamatematikaa (Ormrod, 2004).

Oleh karenanya disini, guru menganggap permasalahan hasil belajar siswa perlu di tingkatkan, karenanya jika di biarkan maka nilai siswa tidak akan mengalami kemajuan. Selanjutnya guru melakukan wawancara terhadap beberapa siswa, yang hasilnya adalah siswa jenuh dan merasa bosan dengan pembelajaran di kelas. Dari hasil wawancara itulah, guru berinisiatif menggunakan model pembelajaran yang tidak biasa di pakai di kelas, yakni menggunakan media benda konkret.

Berdasarkan latar belakang nasalah di atas, peneliti hendak melakukan penelitian dengan judul "Peningkatan Hasil Belajar Siswa Pada KD 3.6 Menjelaskan dan Menemukan Jaring-Jaring Bangun Ruang Sederhana (Kubus Dan Balok) Melalui Penggunaan Media Benda Konkret di Kelas V SD Negeri 5 Madurejo Tahun Pelajaran 2017/2018"

Adapun Identifikasi Masalah dalam penelitian ini adalah:

I. Hasil Belajar Siswa Pada Mepel matematika KD 3.6 Menjelaskan dan menemukan jaring-jaring bangun ruang sederhana (kubus dan balok) masih rendah
2. Belum dilaksanakannya Penggunaan media benda konkret di Kelas V SD Negeri 5 Madurejo Tahun Pelajaran 2017/2018.

\section{TINJAUAN PUSTAKA}

\section{A. Hasil Belajar}

\section{Pengertian Hasil Belajar}

Belajar dan mengajar merupakan konsep yang tidak bisa dipisahkan. Beajar merujuk pada apa yang harus dilakukan seseorang sebagai subyek dalam belajar. Sedangkan mengajar merujuk pada apa yang seharusnya dilakukan seseorang guru sebagai pengajar.

Dua konsep belajar mengajar yang dilakukan oleh siswa dan guru terpadu dalam satu kegiatan. Diantara keduannya itu terjadi interaksi dengan guru. Kemampuan yang dimiliki siswa dari proses belajar mengajar saja harus bisa mendapatkan hasil bisa juga melalui kreatifitas seseorang itu tanpa adanya intervensi orang lain sebagai pengajar. Belajar

2. Faktor-faktor yang Mempengaruhi Hasil

Hasil belajar yang dicapai siswa dipengaruhi oleh dua faktor yaitu yang berasal dari dalam diri siswa dan faktor dari luar diri siswa.

Menurut Caroll (dalam Sudjana 2009:40) terdapat lima faktor yang mempengaruhi hasil belajar siswa antara lain: (I) bakat siswa; (2) waktu yang tersedia bagi siswa; (3) waktu yang diperlukan guru untuk menjelaskan materi; (4) kualitas pengajaran; dan (5) kemampuan siswa. 


\section{B. Media Benda Konkret}

I. Pengertian Media Konkret

Konkret berarti nyata dapat dibuktikan dalam pengertiannya. Seperti yang diungkapkan Rodhatul Jennah (2009:79) bahwa objek adalah "benda sebenarnya yang dapat dijadikan sebagai media pembelajaran" media konkret perlu digunakan untuk mempermudah peserta didik di dalam proses pembelajaran untuk mencapai tujuan pengajaran. Sedangkan menurut Ibrahim dan Syaodih (2003:1/8), yang dimaksud media konkret yaitu " untuk mencapai hasil yang optimal dari proses belajar mengajar salah satu yang disarankan dalam digunakannya pula media yang bersifat langsung, bersifat nyata atau realita". Benda konkret yang sesungguhnya akan memberikan ransangan yang amat penting bagi peserta didik dalam mempelajari berbagai hal, terutama yang menyangkut pengembangan keterampilan tertentu. Melalui penggunaan media konkret ini, kegiatan belajar mengajar dapat melibatkan semua indera peserta didik, terutama indera peraba.

2. Contoh Media Konkret

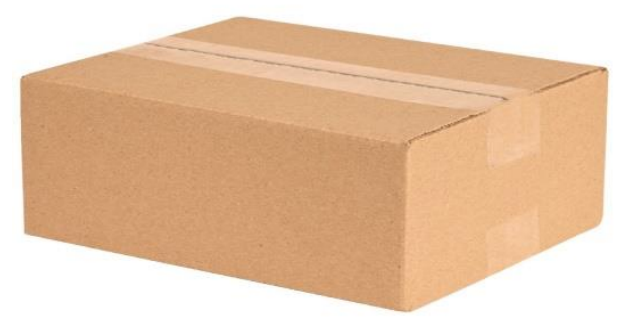

Gambar Kotak Kardus

3. Manfaat Media Konkret

Media konkret merupakan suatu media nyata yang digunakan dalam proses belajar mengajar dimana nantinya akan berpengaruh terhadap hasil pembelajaran yang lebih baik.

\section{Menjelaskan dan menemukan jaring-jaring bangun ruang sederhana (kubus dan balok) \\ I. Kubus}

Kubus merupakan sebuah bangun ruang yang terbentuk oleh enam buah sisi yang saling berbatasan dimana tiap sisi tersebut berbentuk persegi dengan ukuran yang sama besar. Sehingga apabila kita membelah sebuah kubus kemudian meletakkannya pada posisi mendatar akan diperoleh jaring-jaring kubus yang merupakan susunan dari enam buah persegi seperti terlihat pada gambar di bawah ini:

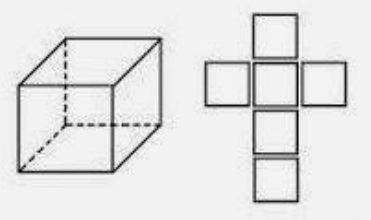

2. Balok

Sama halnya seperti kubus, balok juga terdiri dari enam buah sisi akan tetapi ukuran sisi pada balok berbeda. Ada 3 pasang sisi yang memiliki ukuran sama. Sehingga jika digambarkan, jaring-jaring dari sebuah balok akan menjadi seperti ini:

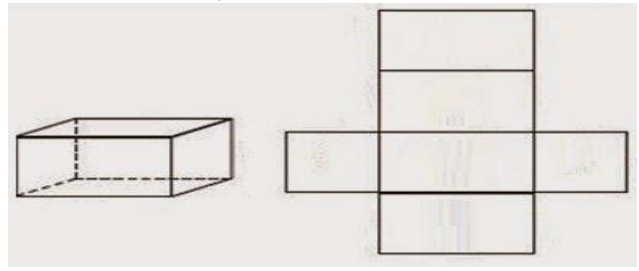

\section{METODE PENELITIAN}

\section{A. Tempat dan Waktu Penelitian}

Penelitian tindakan kelas ini dilakukan di SD

Negeri 5 Madurejo, pada Kelas $V$ dengan jumlah siswa 29 siswa.

I. Profile Sekolah

Adapun waktu dan kegiatan penelitian ini di paparkan sebagai berikut:

Tabel I Waktu Dan Kegiatan Penelitian

\begin{tabular}{|l|l|}
\hline \multicolumn{1}{|c|}{ Bulan } & \multicolumn{1}{|c|}{ Kegiatan } \\
\hline Januari & $\begin{array}{l}\text { Mempersiapkan refrensi dan } \\
\text { bahan penelitian }\end{array}$ \\
\hline Januari & $\begin{array}{l}\text { Konsultasi dengan kepala sekolah } \\
\text { dan teman-teman guru, } \\
\text { Menyusun proposal }\end{array}$ \\
\hline Februari & $\begin{array}{l}\text { Pelaksanaan Siklus I lanjut analisis } \\
\text { data }\end{array}$ \\
\hline Februari & $\begin{array}{l}\text { Pelaksanaan Siklus I lanjut analisis } \\
\text { data }\end{array}$ \\
\hline Februari & Menambah refrensi penelitian \\
\hline Maret & Menyusun laporan penelitian \\
\hline
\end{tabular}

\section{B. Metode Penelitian}

Pendekatan Penelitian ini menggunakan pendekatan kualitatif kuantitatif. Rancangan penelitian metode campuran (mixed methods research design) adalah suatu prosedur untuk mengumpulkan, menganalisis, "dan mencampur" metode kuantitatif dan kualitatif dalam suatu penelitian atau serangkaian penelitian untuk memahami permasalahan penelitian (Cresswell\&Plano Clark, 20II).

Asumsi dasarnya adalah penggunaan metode kuantitatif dan kualitatif secara gabungan. Berdasarkan asumsi tersebut, memberikan pemahaman yang lebih baik tentang permasalahan dan pertanyaan penelitian daripada jika secara sendiri - sendiri.

Pada pelaksanaannya dibutuhkan ketrampilan tertentu dalam penggunaan metode ini, yaitu : (I) prosedurnya memakan banyak waktu, (2) membutuhkan pengumpulan, (3) analisis data ekstensif.

\section{Populasi dan Sampel Penelitian}

Adapun populasi penelitian ini adalah seluruh siswa SD Negeri 5 Madurejo tahun ajaran 2017/2018, sedangkan sampel penelitian ini adalah siswa Kelas V SD Negeri 5 Madurejo. 


\section{Variabel Penelitian}

Variabel penelitian adalah segala kondisi yang diobservasi dikontrol bahkan dimanipulasi oleh peneliti ketika melakukan penelitian, definisi ini menurut salah satu pakar yakni Y.W Best. Lebih khusus, Direktorat Pendidikan Tinggi Depdikbud mendefinisikannya sebagai semua hal yang dijadikan objek dalam penelitian.

Dengan begitu variabel adalah komponen terpenting dalam melakukan sebuah penelitian.

Setelah mengetahui pengertian variabel penelitian, Anda juga perlu tahu bahwa variabel penelitian terdiri dari beragam jenis. Jenis variabel ini pun berbeda tergantung dari sifatnya. Salah satunya adalah variabel yang diperoleh dari hubungannya dengan variabel lain. Jenis ini kemudian dibagi lagi ke dalam dua jenis, yaitu variabel bebas dan variabel terikat.

Dalam penelitian ini ada 2 variabel yakni variable bebas dan variable terikat. Adapun variable bebasnya adalah Media benda konkret dan variable terikatnya adalah Hasil Belajar Siswa.

\section{E. Sumber Data Penelitian}

\section{Data Primer}

Data primer dalam penelitian ini di peroleh dari siswa (subjek penelitian melalui pengisian angket dan observasi.

2. Data Sekunder

Adapun data sekunder dalam penelitian ini adalah penilaian sikap siswa yang di peroleh dari hasil observasi.

\section{HASIL PENELITIAN DAN PEMBAHASAN}

\section{A. Deskripsi Hasil Penelitian}

Penelitian Tindakan Kelas ini di lakukan dengan 3 siklus yakni siklus I terdiri dari 3 pertemuan, pertemuan pertama di lakukan tanggal 6 Februari 2017, pertemuan ke 2 tanggal 7 Februari 2017 dan pertemuan ketiga tanggal I 3 Februari 2017, Sedangkan siklus II dilakukan dengan $2 X$ pertemuan, pertemuan pertama tanggal 20 Februari 2017 dan pertemuan kedua tanggal 2I Februari 2017, berikut:

Adapun rincian kegiatannya dalah sebagai

I. Siklus I

a. Perencanaan

Pada siklus ini di lakukan sebanyak $3 X$ pertemuan untuk itu guru menyiapkan 3 Rencana Pelaksanaan Pembelajaran (RPP). Pada setiap pertemuan di siapkan lembar kerja peserta didik (LKP), untuk mengambil data tentang aktifitas guru dan peserta didik peneliti menyiapkan lembar observasi guru dan peserta didik.

Dalam setiap pertemuan, guru melakukan pembagian kelompok dimana setiap kelompok terdiri dari 4/5 peserta didik dan setiap anggota kelompok memiliki kemampuan yang berbeda-beda. Dari semua peserta didik, berikut adalah pembagian kelompoknya:

Tabel 3 pembagian kelompok

Tabel 4.2
Hasil Observasi siklus I

\begin{tabular}{|c|c|c|}
\hline $\mathrm{NO}$ & NAMA & $\begin{array}{l}\text { Pembagian } \\
\text { Kelompok }\end{array}$ \\
\hline $\mathrm{T}$ & & \multirow{5}{*}{$\begin{array}{l}\text { Kelompok } \\
\text { I }\end{array}$} \\
\hline 2 & & \\
\hline 3 & & \\
\hline 4 & & \\
\hline 5 & & \\
\hline 6 & & \multirow{5}{*}{$\begin{array}{l}\text { Kelompok } \\
2\end{array}$} \\
\hline 7 & & \\
\hline 8 & & \\
\hline 9 & & \\
\hline 10 & & \\
\hline II & & \multirow{5}{*}{$\begin{array}{l}\text { Kelompok } \\
3\end{array}$} \\
\hline 12 & & \\
\hline 13 & & \\
\hline 14 & & \\
\hline 15 & & \\
\hline 16 & & \multirow{5}{*}{$\begin{array}{l}\text { Kelompok } \\
4\end{array}$} \\
\hline 17 & & \\
\hline 18 & & \\
\hline 19 & & \\
\hline 20 & & \\
\hline 21 & & \multirow{6}{*}{$\begin{array}{l}\text { Kelompok } \\
5\end{array}$} \\
\hline 22 & & \\
\hline 23 & & \\
\hline 24 & & \\
\hline 25 & & \\
\hline 26 & & \\
\hline 27 & & \multirow{2}{*}{$\begin{array}{l}\text { Kelompok } \\
6\end{array}$} \\
\hline 28 & & \\
\hline
\end{tabular}

b. Pelaksanaan Tindakan

Pada saat pelaksanaan tindakan guru melaksanakan proses pembelajaran mulai dari pembukaan dan sampai kegiatan ahir.

c. Observasi

I. Guru

Aktifiktas pembelajaran yang dilakukan oleh guru dari awal sampai ahir di amatai oleh observer. Pengamatan di lakukan dengan lembar observasi yang telah di sediakan. Hal yang di amati meliputi beberapa aspek, sesuai tabel di bawah ini:

Tabel 4 Lembar Observasi Gu

\begin{tabular}{|l|l|l|l|l|l|}
\hline No & \multicolumn{1}{|c|}{ Hal Yang di Amati } & \multicolumn{4}{|c|}{ Skor } \\
\cline { 3 - 6 } & & I & 2 & 3 & 4 \\
\hline A & Kegiatan Pendahuluan & & & & \\
\hline I & $\begin{array}{l}\text { Guru menyapa siswa } \\
\text { dan mengkondisikan } \\
\text { kelas agar siap untuk } \\
\text { belajar }\end{array}$ & & & & \\
\hline 2 & $\begin{array}{l}\text { Salah satu siswa } \\
\text { diminta untuk } \\
\text { memimpin doa. }\end{array}$ & & & & \\
\hline
\end{tabular}




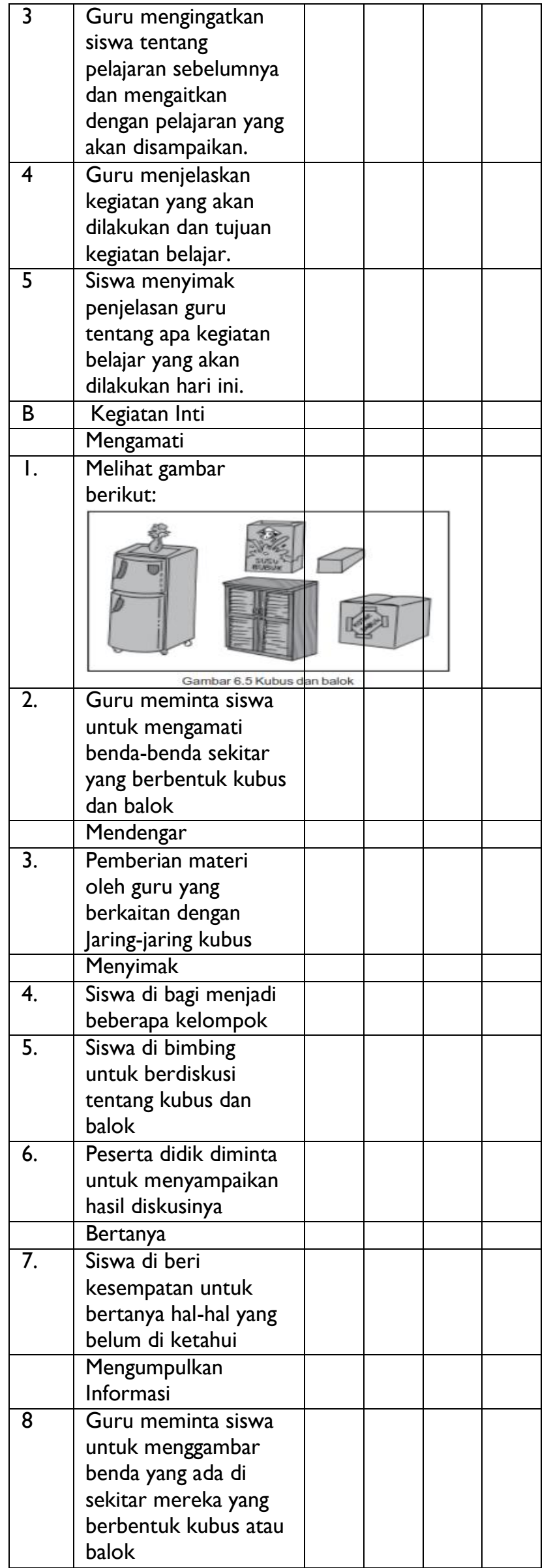

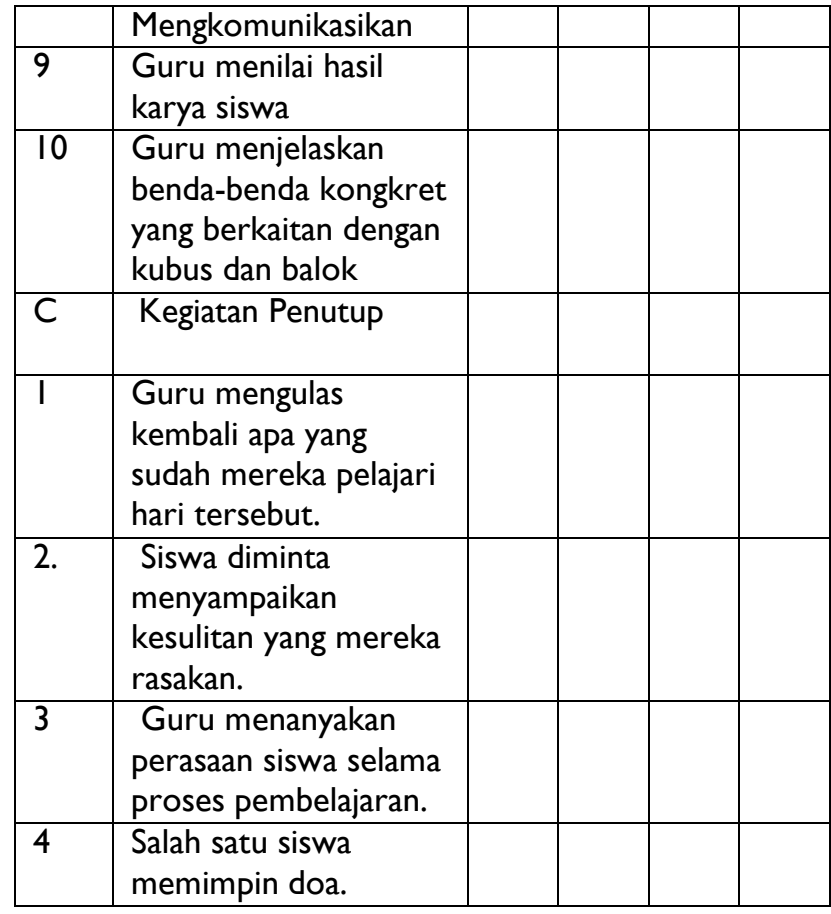

Keterangan:

I : Kurang Baik

2: Cukup Baik

3: Baik

4: Sangat Baik

\section{Peserta didik}

Pada pengamatan peserta didik menggunakan lembar observasi.

\section{d. Refleksi}

Peneliti atau guru bersama-sama dengan observer melakukan refleksi, $m$ embahas permasalahan yang muncul selama proses pembelajaran.Observer memberikan masukan berupa kelebihan dan kekurangan yang terjadi selama proses pembelajaran.

Dari masukan yang di berikan oleh observer akan di gunakan untuk acuan perbaikan kegiatan pembelajaran pada pertemuan berikutnya.

\section{Siklus II}

Langkah kegiatan pada siklus II sama seperti pada siklus I, meliputi perencanaan, pelaksanaan tindakan, observasim evaluasi hasil pembelajaran dan refleksi.Perbedaannya antara siklus I dan II paa tahap pelaksanaan tindakan. Pada siklus II pelaksanaan tindakan di lakukan sebanyak $2 \mathrm{X}$ pertemuan.

\section{B. Hasil Penelitian}

\section{Hasil Penelitian Siklus I}

a. Observasi Terhadap Guru

Data rata-rata skor yang di peroleh mulai pertemuan pertama sampai ketiga cenderung meningkat. Pertmuan pertama masih dalam ketegoro B (Baik) namun skornya lebih rendah dari pertemuan 
kedua dan ketiga. Ini menunjukkan bahwa guru masih berusaha menyesuaikan dengan metode pembelajaran yang baru di terapkan.

b. Observasi peserta didik

c. Evaluasi Hasil Belajar Peserta Didik

d. Refleksi

\section{Perbandingan Hasil Siklus I dan Siklus II \\ I. Hasil Observasi Guru}

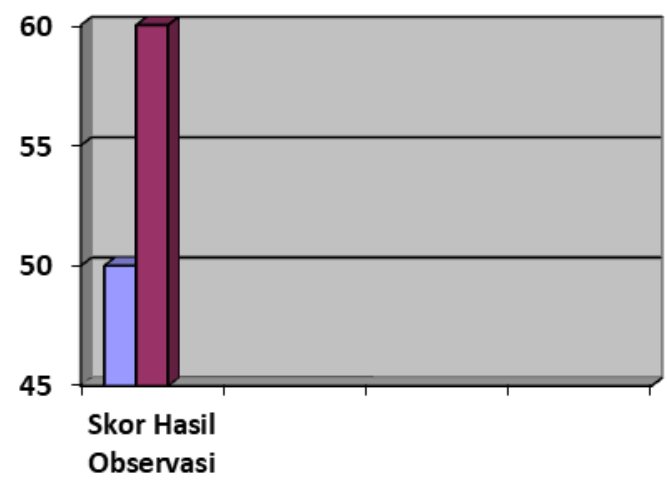

Grafik I hasil Observasi Guru Siklus I dan II

\section{Perbandingan Hasil Observasi Peserta}

Didik Siklus I dan II

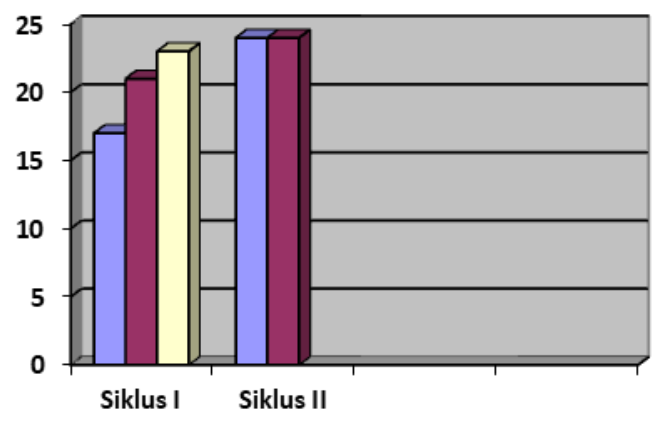

Grafik 2 Perbandingan Hasil Observasi Peserta Didik Siklus I dan II

\section{PEMBAHASAN}

- Hasil Observasi terhadap guru mulai pertemuan ke I,2,3 Siklus I sampai pertemuan ke I dan 2 pada siklus II menunjukkan peningkatan yang signifikan. Ini terlihat dari pertmeuan I,2,3 siklus I mencapai kategoro Baik (B), sedangkan pada pertemuan I dan 2 siklus II mencapai kategori amat baik. Demikian pula di lihat dari perbandingan siklus I dan II rata -rata skornya meningkat, ini menunjukkan dalam proses pembelajaran di kelas, guru menggunakan metode pembelajaran dengan baik.
- Hasil observasi Aktifitas belajar peserta didik mulai dari pertemuan ke I,2,3 siklus I sampai pertemuan k el dan 2 siklus II menunjukkan peningkatan yang signifikan. Hal ini terlihat dari siklus I pertemuan I menghasilkan skor rata-rata I6,5 artinya Aktifitas belajar siswa baik, lalu pada pertmuan ke menghasilkan skor 20,3 selanjutnya pada pertemuan ke 3 menghasilkan skor 23. Pada siklus II pertemuan ke I dan 2 menghasilkan skor 24 artinya Aktifitas belajar siswa sangat baik.

\section{Persepsi Peserta Didik Terhadap Proses Pembelajaran}

Di ahir siklus II, guru memberikan angket untuk mengsahuj ipersepsi peserta didik terhadap peroses pembelajaran menggunakan media benda konkret dalam kegiatan belajar mengajar. Hasil pemberian angket ters@but menunjukkan $98 \%$ peserta didik memberikan tanggapan positif terhadap penerapan Penggunaan media benda konkret. Peserta didik mengungkapkan terbantu dalam menyerap materi pembelajaran.

\section{PENUTUP}

\section{A. Kesimpulan}

Hasil observasi aktifitas belajar peserta didik mulai dari pertemuan ke I,2,3 siklus I sampai pertemuan kel dan 2 siklus II menunjukkan peningkatan yang signifikan. Hal ini terlihat dari siklus I pertemuan I menghasilkan skor rata-rata 16,5 artinya minat belajar siswa baik, lalu pada pertmuan ke menghasilkan skor 20,3 selanjutnya pada pertemuan ke 3 menghasilkan skor 23. Pada siklus II pertemuan ke I dan 2 menghasilkan skor 24 artinya minat belajar siswa sangat

\section{baikertemuan 1.}

Hasil evaluasi siklus I Pada pertemuan ke I PRsertepquabllik yang mendapatkan hasil belajar di atas KKM $\geq 63$ sebanyak 17 siswa atau 64,5\%. Sedangkan peserta didik yang mendapatkan nilai $\leq 63$ sebanyak 12 siswa atau $35,4 \%$. Pada pertemuan ke 2 peserta didik yang mendapatkan hasil belajar di atas KKM $\geq 63$ sebanyak 20 siswa atau 69,2\%. Pada pertemuan ke 2 peserta didik yang mendapatkan hasil belajar di bawah KKM $\leq 63$ sebanyak 9 siswa atau 30,7\%. Pada pertemuan ke 3 peserta didik yang mendapatkan hasil belajar di atas KKM $\geq 63$ sebanyak 23 siswa atau 80,7 $\%$. Sedangkan peserta didik yang mendapatkan nilai $\leq 63$ adalah 6 siswa atau 19,23\%.

Hasil evaluasi siklus II Pada pertemuan ke I peserta didik yang mendapatkan hasil belajar di atas KKM $\geq 63$ sebanyak 26 siswa atau $88,4 \%$. Sedangkan peserta didik yang mendapatkan nilai $\leq 63$ adalah 3 siswa atau II,5\%. Pada pertemuan ke 2 peserta didik yang mendapatkan hasil belajar di atas KKM $\geq 63$ sebanyak 29 siswa atau $100 \%$. Pada pertemuan ke 2 peserta didik yang mendapatkan hasil belajar di atas $\mathrm{KKM} \leq 63$ sebanyak 0 siswa atau $0 \%$.

\section{B. Saran}


Dalam penelitian ini ada beberapa hal yang perlu mendapat perhatian yang merupakan saran peneliti kepada para pembaca umumnya, serta pihak- pihak yang berkepantingan, yaitu :

I. Penggunaan media benda konkret dapat diterapkan pada kelas yang mempunyai karakteristik seperti kelas yang dijadikan subjek penelitian ini.

2. Hendaknya pembelajaran dengan Penggunaan media benda konkret ini dicoba untuk diterapkan pada mata pelajaran yang lain.

\section{DAFTAR PUSTAKA}

Azhar Arsyat, Media Pembelajaran, Jakarta : PT. Grafindo Persada, 2003 Basyiruddin Usman, Media

Pembelajaran, Jakarta: Ciputat Pers : 2002

Departemen Pendidikan dan Kebudayaan, Kamus Besar

Bahasa Indonesia, Bandung : Balai Pustaka, 1990

http://gurulPA.wordpress.com/category/pembelajaran/P age/3/tanggal 13 juni 2015 Imam Nawawi, Terjemah

Riyadhus Shalihin, Jakarta: Pustaka Amani, 1999

Iqbal Hasan, Analisis Data Penelitian Dengan Statistik, Jakarta: Bumi Aksara, 2004

Koentjaraningrat, Metode-metode Penelitian

Masyarakat, Jakarta: PT. Gramedia, 199I

M. Arifin, Filsafat Pendidikan Islam, Jakarta: Bumi Aksara, 1996

Muhammad Ali, Strategi Penelitian Pendidikan Statistik Bandung, Bumi Aksara, 1993

Muhibbin Syah, Psikologi Pendidikan Dengan

Pendekatan Baru, Bandung: Remaja Rosdakarya Offset,

2002

Mukhtar, Desain Pembelajaran Pendidikan Agama Islam, Jakarta : Mizaka Gazila, 2003

Ramdhani, M. T. Certified Islamic Religion Teacher (PAI) to Commitment and Discipline on Junior High School (SMP) and Senior High School (SMA), Palangkaraya. 